\title{
A formação científica e profissional das mulheres no Brasil: A contribuição de Bertha Lutz
}

\author{
Maria Izabel Siciliano de Souza \\ Maria Ferreira Abdala-Mendes
}

\section{Resumo}

Este trabalho visa contribuir para os estudos sobre o papel da mulher na ciência brasileira com base nas análises realizadas sobre a presença de mulheres cientistas nas instituições de pesquisa em diferentes áreas de conhecimento. Para isso, baseamos nosso estudo na vida profissional e científica da zoóloga e ativista feminista Bertha Lutz (1894-1976), defensora incansável dos direitos das mulheres no Brasil, inclusive do direito à Educação e à formação científica. Em 1919, Bertha Lutz prestou concurso público para o Museu Nacional, onde trabalhou por quarenta e seis anos e construiu uma reputação internacional como cientista. Fundou a associação feminista intitulada Liga Pela Emancipação Intelectual da Mulher e dedicou-se intensamente às ciências e ao movimento feminista. Procuramos promover um paralelo entre as reflexões teóricas sobre gênero e ciência, feminismo na ciência e as trajetórias de mulheres nas ciências, no cenário da educacional brasileiro até o fim da década de 1930 e, consequentemente, sobre o papel da mulher nos espaços científicos e acadêmicos a partir das ações de Bertha Lutz no início do século XX e a formação científica e profissional das cientistas brasileiras atualmente. Relacionamos seu papel como pioneira e seu legado a partir da posição tomada por Bertha Lutz na imprensa como local de luta e de divulgação. Com isso, foi possivel relacionar as ações desta cientista com o que temos e tratamos com naturalidade hoje, a formação científica e profissional atual das mulheres e as ações das cientistas pioneiras no cenário científico e político do Brasil no início do século XX.

Palavras-chave: Mulheres na Ciência; Gênero e Ciência; Bertha Lutz.

\begin{abstract}
This work aims to contribute to the studies on the role of women in Brazilian science based on the analyzes carried out on the presence of female scientists in research institutions in different areas of knowledge. For that, we base our study on the professional and scientific life of the zoologist and feminist activist Bertha Lutz (18941976), a tireless advocate for women's rights in Brazil, including the right to education and scientific training. In 1919, Bertha Lutz publicly bid for the National Museum, where he worked for forty-six years and built an international reputation as a scientist. He founded the feminist association titled the League for the Intellectual Emancipation of Women and devoted himself intensely to the sciences and the feminist movement. We seek to promote a parallel between the theoretical reflections on gender and science, feminism in science and the trajectories of women in the sciences, on the Brazilian educational scenario until the end of the 1930s and, consequently, on the role of women in scientific and academic spaces from the actions of Bertha Lutz in the early twentieth century and the scientific and professional training of Brazilian scientists today. We relate his role as a pioneer and his legacy from the position taken by Bertha Lutz in the press as a place of struggle and outreach. With this, it was possible to relate the actions of this scientist with what we have and we deal with naturalness today, the current scientific and professional training of women and the actions of pioneering scientists in the scientific and political scenario of Brazil in the early twentieth century.
\end{abstract}

Keywords: Women in Science; Gender and Science; Bertha Lutz.

\section{INTRODUÇÃO}

Muitos estudos nacionais analisam, entre outras questões, a presença de mulheres cientistas em instituições de pesquisa e sua participação em diferentes áreas de conhecimento, bem como as 
práticas, objetivos e definições históricas que desenharam um meio científico reprodutor de estereótipos de gênero, preconcepções e preconceitos sobre as mulheres, sobretudo, no campo cognitivo. Lima e Souza ${ }^{1}$ evidenciam que os estudos sobre mulheres no meio científico e acadêmico compreendem análises sobre a presença, a colocação e a visibilidade das mulheres nas instituições científicas; sobre o questionamento dos modos de produção do conhecimento e os princípios do pensamento científico hegemônico e os discursos e as representações das mulheres na ciência e as repercussões nos conteúdos de diversas disciplinas.

Através de reflexões sobre gênero e ciência, feminismo na ciência e sobre as trajetórias de mulheres nas ciências, passando pelo cenário da Educação no Brasil até o fim da década de 1930 e, consequentemente, qual o papel da mulher nos espaços científicos e acadêmicos ensino de ciências, acreditamos ser possível traçar um paralelo das ações passadas com o que temos e tratamos com naturalidade hoje. Dessa forma, procuramos destacar a contribuição histórica das cientistas brasileiras na formação científica e profissional das mulheres, na primeira metade do século XX no Brasil, a partir das ações da cientista Bertha Lutz tanto no campo científico como no campo político.

Neste contexto, este estudo busca analisar a vida profissional e científica de Bertha Lutz (18941976), zoóloga, ativista feminista e uma defensora incansável dos direitos das mulheres no Brasil, inclusive do direito à Educação e à formação científica. Em 1919, prestou concurso público para o Museu Nacional, onde trabalhou por quarenta e seis anos e construiu uma reputação internacional como cientista. Fundou a associação feminista intitulada Liga Pela Emancipação Intelectual da Mulher e dedicou-se, intensamente, às ciências e ao movimento feminista.

Nossa análise baseou-se em artigos e livros referentes a sua trajetória e ações e em notícias veiculadas pela imprensa ou mesmas publicadas pela cientista à época, para estabelecermos relações teóricas com as ideias atuais sobre gênero e ciência, história das mulheres na ciência e feminismo e ciência. Com isso, evidenciamos os fatos históricos da introdução das mulheres no cenário político e educacional no Brasil, no início do século XX ao relacionar a trajetória política e científica desta cientista e feminista brasileira e a luta por direitos na formação científica e profissional das mulheres.

\section{A ATUAÇÃO E VISIBILIDADE DAS MULHERES NAS INSTITUIÇÕES CIENTÍFICAS}

Em 1817, Maria Leopoldina Josefa Carolina, a princesa Leopoldina (1797-1826), que mais tarde se tornaria imperatriz, desembarcou no Brasil e trouxe consigo uma bagagem digna da aristocracia, e uma comitiva também a altura. Além disso, também embarcou com ela uma consciência política até então desconhecida por aqui em uma mulher. O Museu de Arte do Rio (MAR) realizou em 2016 uma

\footnotetext{
1 Ângela M. F. de Lima e Souza, "O Viés Androcêntrico em Biologia," in Feminismo, Ciência e Tecnologia, org. A. A. A. Costa \& C. M. B. Sardenberg, 77-88 (Salvador: REDOR/NEIM-FFCH/UFBA, 2002).
} 
exposição comemorativa dos 200 anos da chegada de D. Leopoldina, "com Leopoldina, princesa da Independência, das artes e das ciências, o MAR amplia seu compromisso com a pluralidade de histórias do Rio de Janeiro e seus sujeitos". Esta frase fazia parte do texto de parede introdutório da exposição. Tal conscientização política também é destacada em uma vitrine da exposição, a partir do manifesto "Carta das senhoras baianas à sua alteza real dona Leopoldina", que a felicita pela participação da princesa nas patrióticas resoluções do príncipe regente. Uma exposição que mostrou uma história muitas vezes silenciada, a história de uma mulher, interessada por ciências, arte e política. Uma mulher dotada de interesses além dos que se esperava de seu papel de esposa e mãe, ainda que uma privilegiada e membro da realeza, até hoje essas outras facetas eram desconhecidas.

Trabalhos como os de Prantner ${ }^{2}$ e Ribeiro ${ }^{3}$ ajudam a resgatar a relevância histórica da primeira imperatriz do Brasil, Dona Leopoldina, como um ser completo, não apenas uma esposa real. Este silenciamento da mulher, como sujeito histórico, ocorre em inúmeras áreas do conhecimento, não apenas nas ciências. Mas, especificamente nas ciências, este silenciamento torna muito importante uma reflexão sobre o pensamento científico hegemônico e o perfil androcêntrico da ciência. Donna Haraway analisa as perspectivas feministas sobre o fazer ciência, discutindo também sobre a objetividade da ciência como sendo "um texto contestável e um campo de poder; o conteúdo é a forma"4. Portanto, a forma como a ciência se apresenta e sua objetividade está sempre relacionada a um tipo de saber universal, imparcial, concreto, real, ideológico. Tudo de que o feminismo se distancia, uma vez que, ainda segundo Haraway:

O feminismo ama outra ciência: a ciência e a política da interpretação, da tradução, do gaguejar e do parcialmente compreendido. 0 feminismo tem a ver com as ciências dos sujeitos múltiplos com (pelo menos) visão dupla. $O$ feminismo tem a ver com uma visão crítica, consequente com um posicionamento crítico num espaço social não homogêneo e marcado pelo gênero. ${ }^{5}$

Assim, o feminismo se aproxima mais das visões parciais, das histórias individuais, dos saberes localizados, das interpretações limitadas, e não do que é universal, ou do discurso do que é universal, na medida em que concordamos com a autora de que o universal não existe. Londa

\footnotetext{
2 Johanna Prantner, Imperatriz Leopoldina do Brasil: A Contribuição da Casa Habsburg-Lothringen e da Cultura Austríaca ao Desenvolvimento do Brasil Durante a Monarquia no Século XIX (Rio de Janeiro: Vozes, 1997).

${ }^{3}$ Arilda A. Ribeiro, "Contribuição da Imperatriz Leopoldina à Formação Cultural Brasileira (1817-1826)," in Anais Eletrônicos do XXIII Simpósio Nacional de História, 1-8 (Londrina: ANPUH PR, 2005), http://anais.anpuh.org/wp-content/uploads/mp/pdf/ANPUH.S23.0144.pdf (acessado em 01 de setembro de 2017).

4 Donna Haraway, "Saberes Localizados: A Questão da Ciência para o Feminismo e o Privilégio da Perspectiva Parcial," Cadernos Pagu, n०5 (1995): 10.

5 Ibid., 25.
} 
Schienbinger, professora de História da Ciência na Pennsylvania State University, concluiu em seu livro “O Feminismo mudou a ciência?" em 1999, que "o feminismo mudou de muitas maneiras o conteúdo do conhecimento humano"6. Sua pesquisa em diversas áreas das ciências - como Medicina, rimatologia, Arqueologia, origens humanas, Biologia, Física e Matemática -, indica que vários novos enfoques foram dados à ciência graças ao feminismo, desde a criação de políticas de saúde pública visando a saúde da mulher, até a inclusão de novos tipos de objetos, menos bélicos e mais específicos como, por exemplo, objetos de interesse para a arqueologia.

A atuação das mulheres como produtores nos meandros das ciências trouxe novos olhares e interpretações para campos já há muito estabelecidos. A experiência como sujeito dominado nas relações de gênero adiciona perguntas impossíveis de serem formuladas pelos sujeitos da dominação. Nestes casos, as vivências distintas acrescentam novas visões, novos pontos de vista que, na maioria das vezes, mudam a forma de fazer e compreender a ciência.

No Brasil, segundo Santos ${ }^{7}$, o feminismo gerou uma reação diferenciada, onde as feministas não procuraram inserir seus novos vieses, mas associar-se ao discurso já estabelecido. Naquele contexto, insere-se a atuação de Bertha Lutz. Na publicação Cartas de Mulher ${ }^{8}$, na Revista da Semana ${ }^{9}$, a cientista e ativista reforçou como as mulheres não deviam se deixar dominar, porém deveriam dar provas de seu valor para merecer ocupar novos espaços.

Não devemos resignar-nos a ser as únicas subalternas num mundo ao qual a liberdade sorri. Devemos tornar-nos dignas da posição que ambicionamos e dar provas do nosso valor para merecê-la. ${ }^{10}$

A mulher deveria se inserir nos espaços já existentes, sendo medidas pelos padrões existentes e considerados, então, universais. Era uma forma de luta pela resistência, pela apropriação dos valores do dominador para que se reconheça um sujeito com valor e merecedor. $O$ que nos permite entender a inserção no pensamento e discursos da época, mesmo que fossem machistas.

Ainda que os estudos da presença da mulher na ciência manifestem-se em diferentes perspectivas, assim também as teorias de gênero se apresentam de variadas maneiras. ${ }^{11} 0$ contexto

\footnotetext{
${ }^{6}$ Londa Schienbinger, O Feminismo Mudou a Ciência?, (Bauru, SP: EDUSC, 2001): 329.

7 Juliana A. Santos, "Gênero na Teoria Social: Papéis, Interações e Instituições," Virtu 4 (2007).

${ }^{8}$ Esse e outros textos publicados encontram-se disponíveis na íntegra no site do Museu Bertha Lutz: http://hs.unb.br/bertha/ (acessado em setembro 2017).

${ }^{9}$ De acordo com o livro A Revista no Brasil (2000), a Revista da Semana, fundada por Álvaro de Tefé, começou a circular em 1900, no Rio de Janeiro. Pertencente ao "Jornal do Brasil" até o ano de 1915 foi comprada pela "Companhia Editora Americana", tornando-se mais dedicada a assuntos femininos.

${ }^{10}$ Revista da Semana, $n^{0} 45$ (Rio de Janeiro, 14 de Dezembro de 1918): 16, http://memoria.bn.br/DocReader/docreader.aspx?bib=025909_01\&pasta=ano\%20191\&pesq=somos\%20filhos\%20de (acessado em outubro 2017).
} 
sócio-histórico e as circunstâncias sempre devem ser levados em consideração quando em análise. E mesmo que sejam distintos, é inegável que cada um possui um elemento de luta importante, e atinge o pensamento feminista na História da Ciência, no qual se destaca a atuação e o papel das mulheres no processo de construção do conhecimento cientifico.

Um dos exemplos mais famosos quando falamos de mulheres cientistas é, sem dúvida, Marie Curie (1867-1934). Polonesa, naturalizada francesa, estudou física em Paris com pouquíssimas condições financeiras, e ganhou, em 1903, o prêmio Nobel em Física, por suas contribuições ao entendimento do fenômeno da radioatividade e, em 1911, o prêmio Nobel em Química, pela descoberta dos elementos rádio e polônio. Marie Curie foi a primeira mulher a ganhar um Prêmio Nobel e a primeira pessoa a ganhar o prêmio duas vezes ${ }^{12}$.

Mas a ascensão de madame Curie não transcorreu livre de empecilhos e preconceitos. Segundo Cordeiro13 "influência do machismo na ciência e na educação científica [...] restringe a ciência aos homens". Quando se tem uma história feminina de sucesso geralmente ela se mostra recheada de entraves e limitações, além de terem muitos detalhes apagados com o tempo, o que faz com apaguem modelos de cientistas mulheres para inspirar carreira semelhante.

Apesar de todo o alvoroço em torno de madame Curie ter mais de 100 anos, segundo Chassot $^{14} \mathrm{o}$ ambiente das mulheres que se dedicam às ciências, em termos globais, ainda é hostil. Houve uma melhora significativa nas últimas décadas, com o aumento da presença de mulheres em diferentes áreas da Ciência, mesmo naquelas que antes pareciam domínio quase exclusivo dos homens.

Parece que usualmente não se valorizam significativamente as contribuições femininas. Marie Curie continua sendo quase a única cientista citada nas aulas e se difundem estatísticas desatualizadas, destinadas a mostrar que as meninas são congenitamente incapazes de aprender Matemática. Quando as meninas se destacam em Matemática é porque são esforçadas, mas quando esta é a situação

11 Gayle Rubin, O Tráfico de Mulheres: Notas Sobre a 'Economia Política' do Sexo (Recife: SoS Corpo, 1993), file://C:/Users/Usuario/Downloads/OTraficoDeMulheres.pdf (acessado em 30 setembro de 2017); Joan W. Scott, "Gênero: Uma Categoria Útil de Análise Histórica," Educação \& Realidade 20, n 2 (1995):71-99; Haraway, "Gender' for a Marxist Dictionary: The Sexual Politics of a Word," in Simians, Cyborgs, and Women: The Reinvention of Nature, Haraway, 127-148 (London: Free Association Books Ltd., 1991); Haraway, "Saberes Localizados"; Judith. Butler, Problemas de Gênero: Feminismo e Subversão da Identidade, (Rio de Janeiro: Civilização Brasileira, 2003); Jimena Furlani, Ideologia de Gênero? Explicando as Confusões Teóricas Presentes na Cartilha. (Florianópolis: FAED; UDESC. Laboratório de Estudos de Gênero e Família, 2016), https://drive.google.com/file/d/OBxw_jT3HkWUOcEJxc2dLX3VKcmM/view (acessado em 30 outubro de 2017).

12 Marie Skłodowska Curie dividiu o Nobel de Física com o seu marido Pierre Curie e o físico Henri Becquerel, em 1903; e, em 1911, fo laureada com o Nobel de Química.

${ }^{13}$ Marinês D. Cordeiro, "Questões de Gênero na Ciência e na Educação Científica: Uma Discussão Centrada no Prêmio Nobel de Física de 1903," Atas do IX Encontro Nacional de Pesquisa em Educação em Ciências - IX ENPEC, (Águas de Lindóia, SP, 2013): 6, http://www.nutes.ufrj.br/abrapec/ixenpec/atas/resumos/R1273-1.pdf (acessado em outubro 2017).

${ }^{14}$ Attico Chassot, "A Ciência é Masculina? É Sim Senhora...," Contexto e Educação 19, nº 71/72 (jan.-dez. 2004): 9-28. 
de meninos é porque são inteligentes. Mesmo que se saiba ser essa premissa falsa, ainda hoje a situação é reforçada. ${ }^{15}$

A despeito de um aumento na formação de mulheres em faculdades de ciências, tanto no Brasil quanto na Europa, o prosseguimento da carreira de cientista torna-se bastante complicado, seja pelo viés androcêntrico da ciência, considerada profissão masculina, seja pelas limitações impostas ao comportamento esperado das mulheres. Fato é que, pelo menos no Brasil, na primeira década do século XXI os números já se mostram um pouco mais próximos.

O número de mulheres na ciência hoje em dia é seguramente mais expressivo que há um século - ela, afinal, é feita em grandes grupos e conhece poucas fronteiras. No entanto, nossos livros e escolas continuam com o hábito danoso de festejar apenas um punhado de nomes, escolhidos por valores sociais que, como demonstram os levantes contraculturais, devem ser repensados. ${ }^{16}$

Diante das mais variadas dificuldades enfrentadas pelas mulheres para ter acesso a Educação de qualidade no Brasil, o CNPq, em parceria com a Secretaria de Política para as Mulheres, no âmbito do Programa Mulher e Ciência, lançou em 2013 o projeto "Pioneiras da Ciência no Brasil". Já em sua 6a edição o programa tem o objetivo de "resgatar do esquecimento figuras femininas que inadvertida ou deliberadamente permaneceram ocultas na história da ciência em nosso país"17, e com isso quebrar os estereótipos femininos e tornar públicos modelos com os quais as novas gerações possam se inspirar.

Entre as mais de 70 pesquisadoras de várias áreas que já tiveram suas histórias resgatadas, temos alguns exemplos de mulheres que também participaram ativamente na transformação da ciência até chegar ao que entendemos hoje em dia como tal. Apenas para citar algumas como Elisa FrotaPessoa, atualmente com 97 anos, a segunda mulher a graduar-se em Física no Brasil, enfrentou as objeções do pai e inclusive trabalhou sem salário por um período para se manter no campo da pesquisa, sendo uma das fundadoras do CBPF, Centro Brasileiro de Pesquisas Físicas, em 1949. Ou Nise da Silveira (1905-1999), formada médica aos 21 anos pela Faculdade de Medicina da Bahia, foi perseguida e presa nos anos 1930, teve seu trabalho pioneiro de pesquisa sobre o tratamento da doença mental através da arte-terapia reconhecido internacionalmente. Ou ainda Eloisa Biasoto Mano, nascida em 1924, diplomou-se em Química Industrial em 1947 pela Universidade do Brasil, atualmente Universidade Federal do Rio de Janeiro (UFRJ), foi a responsável pela criação, em 1968, do primeiro

\footnotetext{
15 lbid., 22.

${ }^{16}$ Cordeiro, 7

${ }^{17}$ Nadja P. Santos \& Elisa P. Massena, "As Marcas do Gênero na Ciência: A Formação do Licenciado e do Químico na Antiga FNFI e no Instituto de Química/UFRJ," in VII ENPEC (Florianópolis, 2009): 3-4.
} 
grupo de pesquisadores em polímeros no Brasil e este grupo foi a origem do Instituto de Macromoléculas/UFRJ, criado em 1976.18

Mesmo sendo pouco retratado, não eram poucas as mulheres que participavam do meio científico no Brasil com toda resistência ao seu ingresso no mundo universitário e acadêmico nas primeiras décadas do século XX. Dentre as que exerciam alguma profissão, encontramos médicas, escritoras e pesquisadoras de instituições como o Museu Nacional. Como o caso de Bertha Lutz, zoóloga, ativista feminista, e defensora incansável dos direitos das mulheres no Brasil, inclusive do direito das mulheres à Educação Superior e Científica ${ }^{19}$. Em 1919, prestou concurso público para 0 Museu Nacional, passando a ser a segunda brasileira a ingressar no serviço público. Nessa instituição, trabalhou por quarenta e seis anos e nela construiu uma reputação internacional como cientista.

Lopes $^{20}$ faz um interessante apanhado sobre a presença de mulheres atuando nas Ciências Naturais no Brasil, mostra numa frase marcante acentuada discrepância no tratamento dispensado a homens e mulheres que exerciam a mesma profissão: "Aos homens que enfrentaram as agruras do campo em prol da ciência confere-se 0 atributo de heróis, às mulheres, quanto muito 0 de aventureiras."21

\section{BERTHA LUTZ E SUA CONTRIBUIÇÃO PARA A FORMAÇÃO CIENTíFICA E PROFISSIONAL DAS MULHERES NO BRASIL}

A vida de Bertha Maria Júlia Lutz foi repleta de influências que a transformaram não só em uma cientista como em uma das pioneiras do feminismo no Brasil. Não é possível entender sua trajetória e ações sem relacionar algumas destas influências - como sua infância no colégio da família dirigido pela avó, o convívio com o pai cientista e a mãe enfermeira, sua formação superior científica na Europa, sua entrada no serviço público, a fundação de ligas feministas, seus relacionamentos com mulheres proeminentes no Brasil e nos Estados Unidos, até sua entrada formal na política - as suas efetivas contribuições para a formação científica das mulheres.

Bertha Lutz nasceu em São Paulo no dia 02 de agosto de 1894, filha da enfermeira inglesa Amy Marie Gertrude Fowler e do cientista brasileiro, Adolpho Lutz, especialista em medicina tropical. Seus avôs, Gustav Lutz e Mathilde Oberteuffer, emigraram da Suíça para o Rio de Janeiro em 1849. Adolpho Lutz, seu pai, nasceu na então capital do Império Brasileiro, em 1855, porém, devido a uma

\footnotetext{
${ }^{18}$ Hildete P. Melo \& Ligia M. C. S. Rodrigues, Pioneiras da Ciência no Brasil (Rio de Janeiro: SBPC, 2006).

${ }^{19} \mathrm{O}$ ensino superior foi instituído no Brasil em 1808, porém, a primeira mulher brasileira a possuir um diploma de ensino superior foi Maria Augusta Generoso Estrela, que se graduou em Medicina, no ano de 1882, nos Estados Unidos. No Brasil, apenas em 1887, Rita Lobato Velho Lopes (1867-1954) tornou-se a primeira mulher a se graduar no país na Faculdade de Medicina da Bahia. Em São Paulo, a entrada de uma mulher na tradicional Escola Politécnica só ocorreu em 1928, de acordo com Delcele Queiroz em seu artigo "Mulheres no Ensino Superior no Brasil", na 23a Reunião Anual da ANPED, em 2000.

20 Margareth. M. Lopes, "Aventureiras nas Ciências: Refletindo sobre Gênero e História das Ciências Naturais no Brasil," Cadernos Pagu, n 10 (Campinas, 1998): 345-368.

21 lbid., 367.
} 
epidemia de cólera em 1857, sua família retornou a Berna, onde Adolpho Lutz estudou medicina, obtendo o diploma em 1879. Em 1881, retornou a sua cidade natal e validou seu diploma e sua tese de doutoramento. No ano seguinte, mudou para Limeira, no interior de São Paulo, onde realizou grandes pesquisas e trabalhos pioneiros em medicina veterinária. Amy Marie Gertrude Fowler, mãe de Bertha Lutz, também possui uma trajetória interessante do ponto de vista da mulher na ciência. De acordo com própria Bertha, em relatos gravados mais tarde em sua vida ${ }^{22}$, sua mãe sempre desejou estudar e que havia sido uma enfermeira à procura de uma atividade "apaixonante". Formou-se em Londres e estudou microbiologia no instituto Pasteur. Uma enfermeira famosa servira de inspiração a mãe de Bertha, Florence Nightingale. Florence havia cuidado dos feridos da Guerra da Criméia (1855-1856) e fundou a primeira escola de enfermagem do mundo, profissionalizando o trabalho das enfermeiras. Seu trabalho foi inovador na melhora das condições higiênicas. Tais inovações seriam, mais tarde, adotadas em todos os países. Ao ler uma notícia sobre o desabafo de um médico numa colônia de leprosos em Honolulu, no Havaí, Estados Unidos, sobre a falta de enfermagem suficiente para os doentes, Amy Fowler ofereceu seus serviços, indo para América em 1890. No Havaí, Amy Fowler e Adolpho Lutz se conheceram e se casaram, vindo posteriormente morar no Brasil.

Outra mulher na vida de Bertha que merece especial atenção é sua avó Mathilde Lutz. Fundou um colégio para meninas, o Colégio Suíço-Brasileiro (figura 1), que funcionou primeiro no Catete, depois em Botafogo e por fim na Tijuca, estando aberto aproximadamente do fim da década de 1870 até o fim da década de 1930. Bertha Lutz e suas primas ajudaram no cuidado com os alunos, o que evidencia desde cedo seu envolvimento e de sua família com a Educação, inclusive com a educação de meninas, mesmo que em regime segregado.

Todas essas informações encontram-se na página da Biblioteca Virtual Adolpho Lutz, que é um desdobramento do projeto "Adolpho Lutz e a história da medicina tropical no Brasil", da Casa de Oswaldo Cruz, Fundação Oswaldo Cruz. Bertha Lutz teve importantíssimo papel na reunião, publicação e divulgação do trabalho do pai, deixando todo seu acervo organizado para a posteridade.

Tendo terminado os estudos primários no Brasil, Bertha Lutz, sua mãe e seu irmão se transferem para a Europa para terminar os estudos secundários e superiores. Durante a Primeira Guerra Mundial, viveram num apartamento alugado na capital francesa, porém, antes de se fixarem em Paris passaram uma temporada no Reino Unido, embora não haja muitos registros de tal período. ${ }^{23}$

22 Os áudios estão disponíveis na biblioteca virtual em Saúde da Fiocruz, em "Lutziana- Bertha Lutz": http://www.bvsalutz.coc.fiocruz.br/html/pt/static/imagem_som/audio.php.

${ }^{23}$ Rachel Soihet, "A Pedagogia da Conquista do Espaço Público pelas Mulheres e a Militância Feminista de Bertha Lutz," Revista Brasileira de Educação, nº 15 (set.-dez. 2000): 97-117. 
Em um perfil parlamentar de Bertha Lutz — realizado pela historiadora Teresa Cristina de Novaes Marques e publicado pela própria câmara dos deputados ${ }^{24}$ — há uma linha do tempo que indica a conclusão de seus estudos secundários na cidade de Bath, Grã-Bretanha em 1915, corroborando sua passagem pelo Reino Unido ${ }^{25}$. Esta cidade está localizada a aproximadamente 190 quilômetros de distância de Londres, onde ficava a sede do grupo Women's Social and Political Union (WSPU), mais conhecido como suffragettes. Tal grupo ficou conhecido por perpetrar um conjunto de ações em prol do voto feminino, incluindo ataques contra prédios comerciais e do governo por toda a cidade durante toda a década de 191026. Segundo Soihet, Bertha Lutz interessou-se por participar na campanha feminista, mas foi impedida por sua mãe que a alertou sobre sua condição de menor e estrangeira.

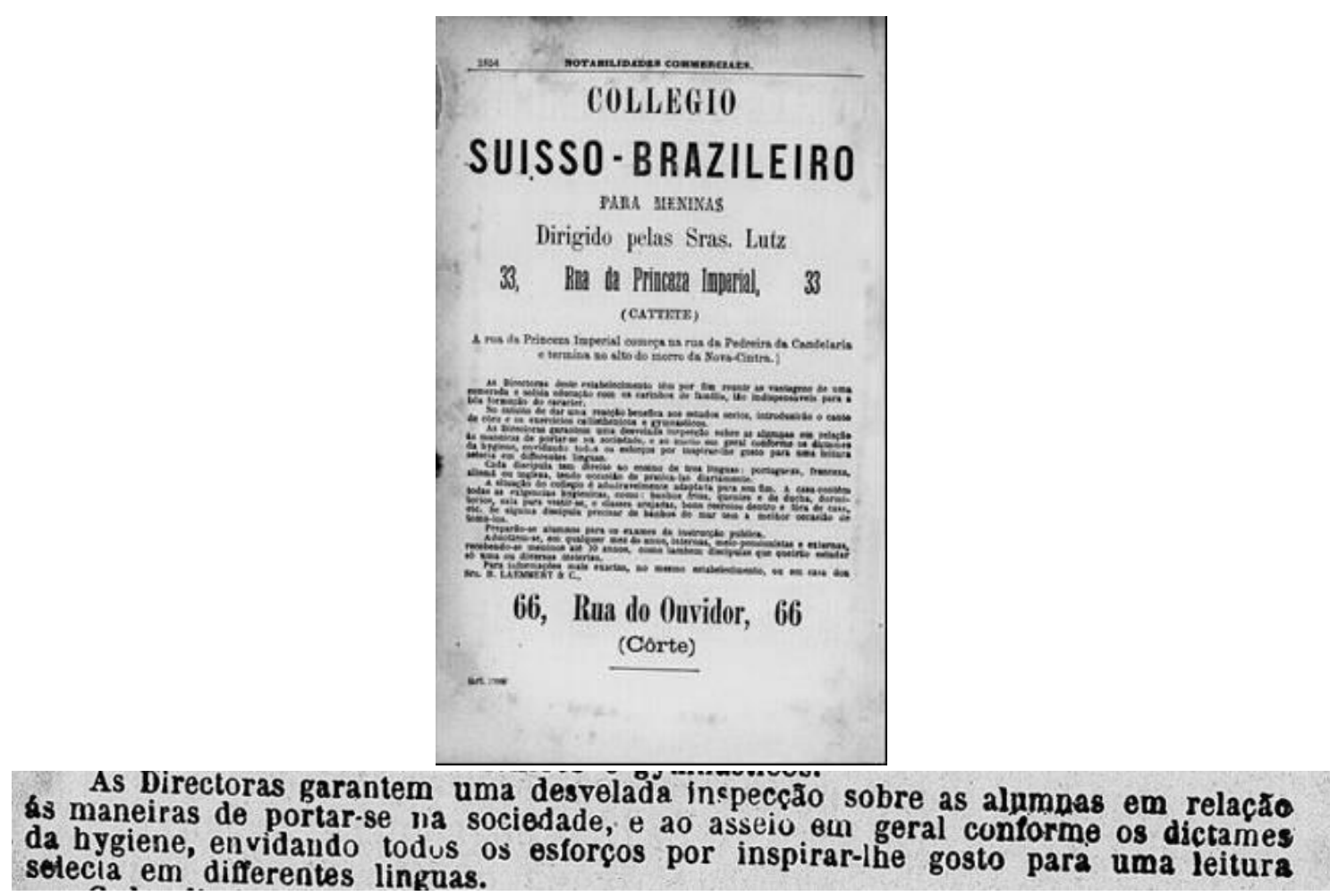

Figura 1: Propaganda da escola dirigida pela avó de Bertha Lutz veiculada na revista Almanak Administrativo, Mercantil e Industrial do Rio de Janeiro, em 1885, página 1854.

A estada de Bertha Lutz em Paris proporcionou-lhe um encontro com Jerônima Mesquita, uma enfermeira brasileira que seria sua companheira de lutas pelas mulheres no Brasil. Inicialmente, Jerônima fundou, no Brasil, o movimento das Bandeirantes em 1919, uma espécie de grupos de escoteiras mulheres e participou, juntamente com Bertha Lutz e outras companheiras da fundação de

\footnotetext{
24 Teresa C. N. Marques, "Bertha Lutz: Série, Perfis Parlamentares," Centro de Documentação e Informação 73, (2016).

25 lbid., 147

${ }^{26}$ Mônica Karawejczyk, "As Suffragettes e a Luta pelo Voto Feminino," História, imagem e narrativas, nº 17 (out. 2013 ): 1-24.
} 
uma organização em defesa da condição da mulher, a Liga pela Emancipação Intelectual das Mulheres, no Rio de Janeiro.

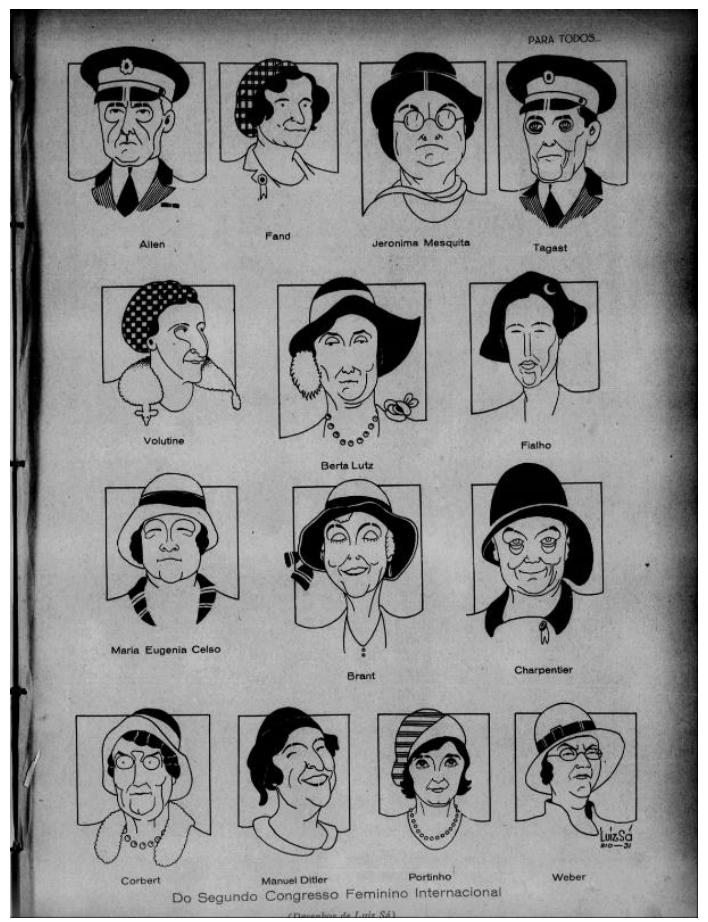

Figura 2: Jerônima Mesquita e Bertha Lutz representadas em caricaturas por ocasião do Segundo Congresso Feminino Internacional no periódico Para Todos, em 1931, na página 11.

O interesse de seus pais pelas ciências influenciou bastante a formação profissional e a carreira de Bertha Lutz. Segundo Lôbo ${ }^{27}$, durante seus estudos na França, na Faculté des Sciences da Universidade de Paris, inúmeras foram suas dúvidas em relação a sua formação e ao seu futuro como cientista. Em algumas cartas, Bertha Lutz mencionou seu desejo de voltar ao Brasil para ficar junto ao pai e assim aprender mais na prática. Em outras anotações questionou se seu verdadeiro interesse seria pela ciência ou pela lógica que esta encerra.

Se entusiasmada pelo pai ou por vontade própria, Bertha Lutz ficou na Europa até se formar e obter o diploma de Licenciée em Sciences, pela Faculté des Sciences da Universidade de Paris, em 1918.

\section{O TRABALHO COM O PAI E A ENTRADA NO SERVIÇO PÚBLICO}

O primeiro contato profissional de Bertha Lutz no Brasil foi como encarregada de Zoologia no Instituto Oswaldo Cruz, sob a tutela de seu pai. Oficialmente, seu trabalho era como tradutora, mas ao mesmo tempo, Bertha preparou-se para dar entrada no serviço público. Em 1919, causou burburinho

${ }^{27}$ Yolanda Lôbo, Bertha Lutz (Recife: Fundação Joaquim Nabuco; Massangana, 2010). 
apenas por se candidatar a vaga de secretário do Museu Nacional (MN). Tal candidatura the rendeu uma entrevista publicada em uma coluna do jornal A Noite, de autor não citado, chamada "Mulheres na Burocracia". A coluna possui um subtítulo interessante "Há uma candidata a secretário do Museu" (figura 3), destacando o fato como inusitado.

Além de fazer uma breve descrição do concurso, há também uma nota sobre a "recente atenção" que o trabalho em atividades burocráticas parece exercer sobre as mulheres daquela época, citando Maria José de Castro Rebello Mendes (1891-1936), a primeira mulher a entrar no serviço diplomático no Brasil. Outros tipos de trabalho são citados como destinados às mulheres, como o de datilógrafas e também alguns trabalhos agrícolas pelo interior do país.

Em tal entrevista, Bertha Lutz mostrou-se preocupada sobre o que dizer, uma vez que considerava este momento muito importante para suas lutas. Por isso sua frase de abertura no jornal $A$ Noite, em 1919: "Sobre o feminismo e o interesse de procurarem as moças brasileiras chegar à posição que a mulher moderna procura, pelo meio do trabalho intelectual, que hei de dizer?". Citando o feminismo e o novo lugar da mulher moderna, considerou que o exemplo de outras mulheres é prova suficiente de que o trabalho é um poderoso instrumento na posição da mulher na busca de seu novo ideal, tanto de emancipação econômica, como de expansão intelectual do trabalho.
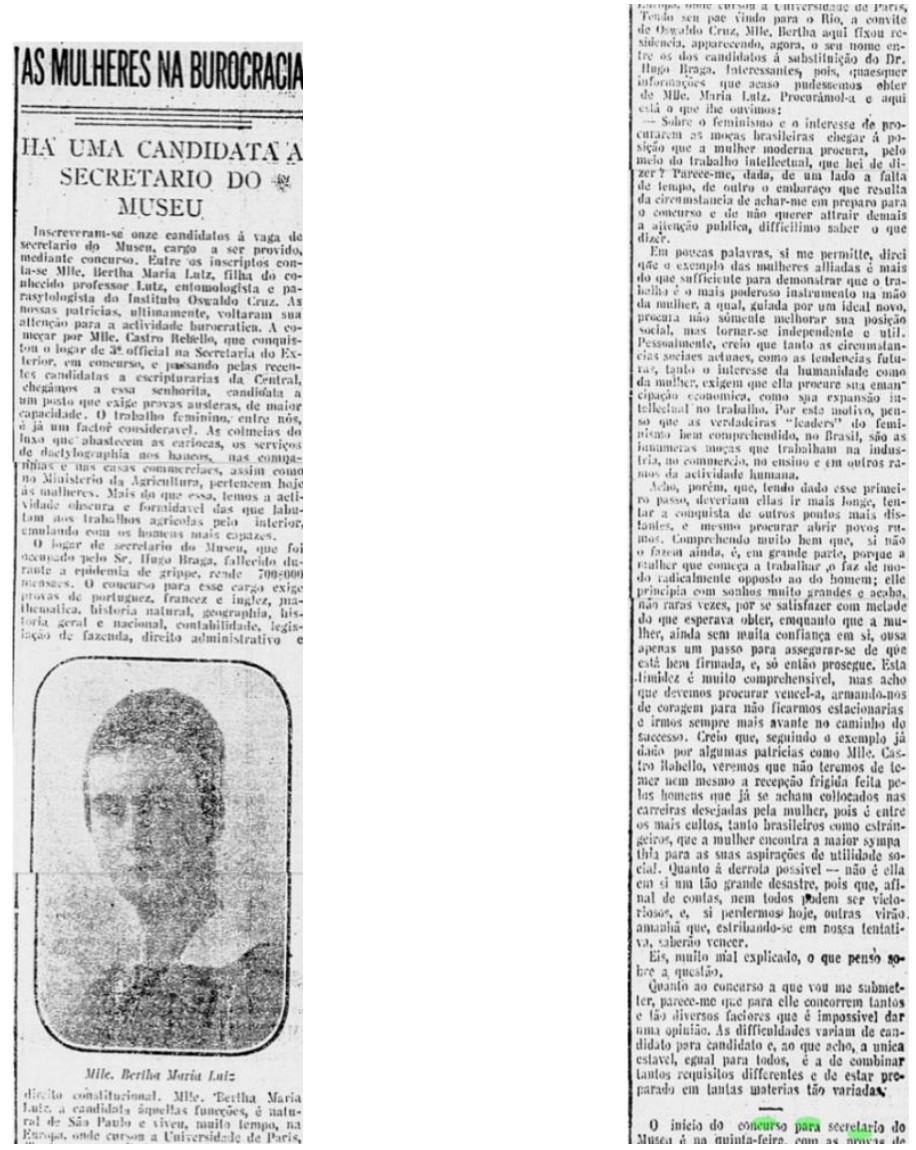

Figura 3: 0 título da matéria do jornal A Noite, em 08 de Julho de 1919, chama atenção para uma mulher ser candidata ao cargo de secretário. 
Aprovada em primeiro lugar no concurso, tomou posse em setembro do mesmo ano, sendo a segunda mulher admitida por concurso e nomeada para cargo federal efetivo por decreto presidencial28. Tal fato, segundo Lôbo ${ }^{29}$, é registrado por Bertha Lutz como uma vitória do movimento feminista, abrindo caminhos para outras mulheres. Apesar de separada de seu pai no trabalho no MN, Bertha Lutz nunca se apartou totalmente dele. Mais tarde, quando Adolpho Lutz já se encontrava com a saúde debilitada, assumiu os trabalhos do pai e passou a estudar os tipos de anfíbios. Também assumiu o papel de arquivista e defensora de seu legado, bem como de toda a história da família.

\section{BERTHA LUTZ NA IMPRENSA}

Paralelamente ao seu trabalho formal, o feminismo ocupou uma grande parte da vida de Bertha Lutz. De acordo com Lôbo ${ }^{30}$, as correspondências com seus amigos europeus marcam a continuação de seu interesse pelo assunto, pedindo informações sobre as feministas inglesas.

A escrita também fez parte de seu cotidiano e Bertha Lutz despontou na imprensa, escrevendo na coluna "Cartas de Mulher", na Revista da Semana, editado pela Companhia Editorial Americana. Tratou sobre igualdade humana em que citava as mulheres na Europa que já partilhavam do governo, e conclamou os brasileiros a se revoltarem contra a inferioridade imposta às mulheres (figura 4). Em outra ocasião (figura 5), uma leitora aponta Bertha Lutz como representante da "nova mulher".

Em 1919, Bertha Lutz e um grupo de companheiras fundaram a Liga para a Emancipação Intelectual da Mulher. Esta união envidaria esforços para que os direitos da mulher fossem reconhecidos, principalmente na luta pelo voto, mas também na participação na vida pública, princípios de salário igual para ambos os sexos, inclusão da mulher no serviço de proteção aos trabalhadores, direitos iguais à Educação, entre outros.

Seu grupo - composto por Stella Guerra Duval, Júlia Lopes de Almeida, Jerônima Mesquita, Valentina Biosca, Esther Salgado Monteiro, Corina Barreiros, Isabel Imbassay Chermont —, era formado por mulheres cultas e ricas, que, segundo Soihet, passaram a se aproveitar de suas conexões, laços de amizades entre suas famílias e grupos no poder, para atiçar a opinião pública, fazer pressão sobre o congresso e obter mais partidários para a causa do sufrágio feminino.

\footnotetext{
${ }^{28}$ Em 1919, Bertha ingressou no Museu Nacional e ocupou diversas funções nos campos da botânica, zoologia e, em especial, na organização do museu e de seus serviços educativos, aposentando-se em 1964.

29 Lôbo, Bertha Lutz.

$30 \mathrm{lbid}$.
} 


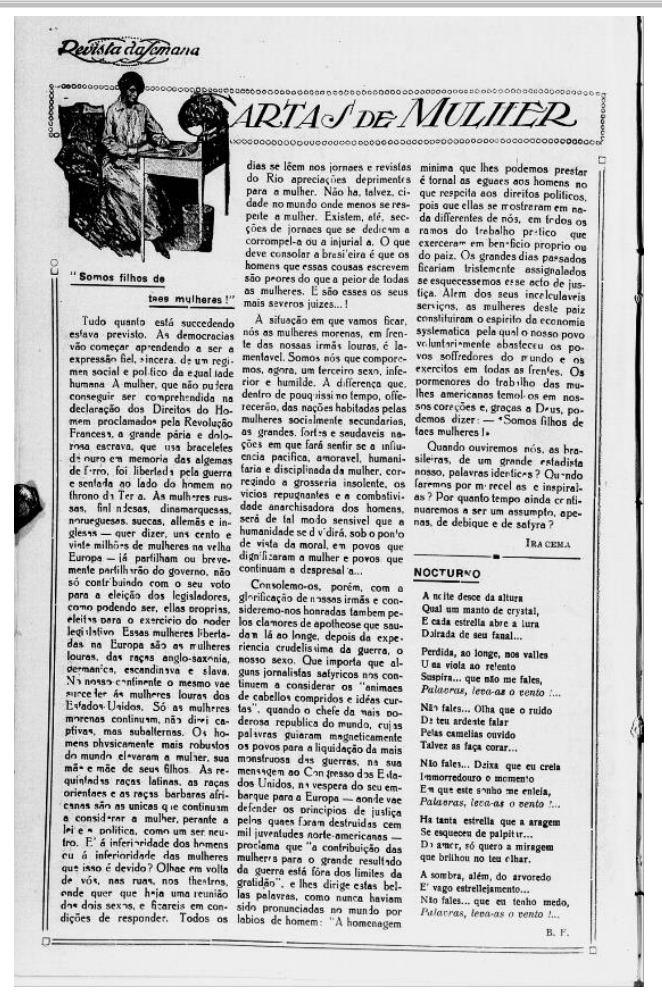

Figura 4: Bertha Lutz - usando um pseudônimo - nomeia as brasileiras de "mulheres morenas" num artigo publicado na Revista da Semana, em 14 de Dezembro de 1918, na página 16, em contraponto às louras da Europa, que já têm mais direitos assegurados junto ao governo.

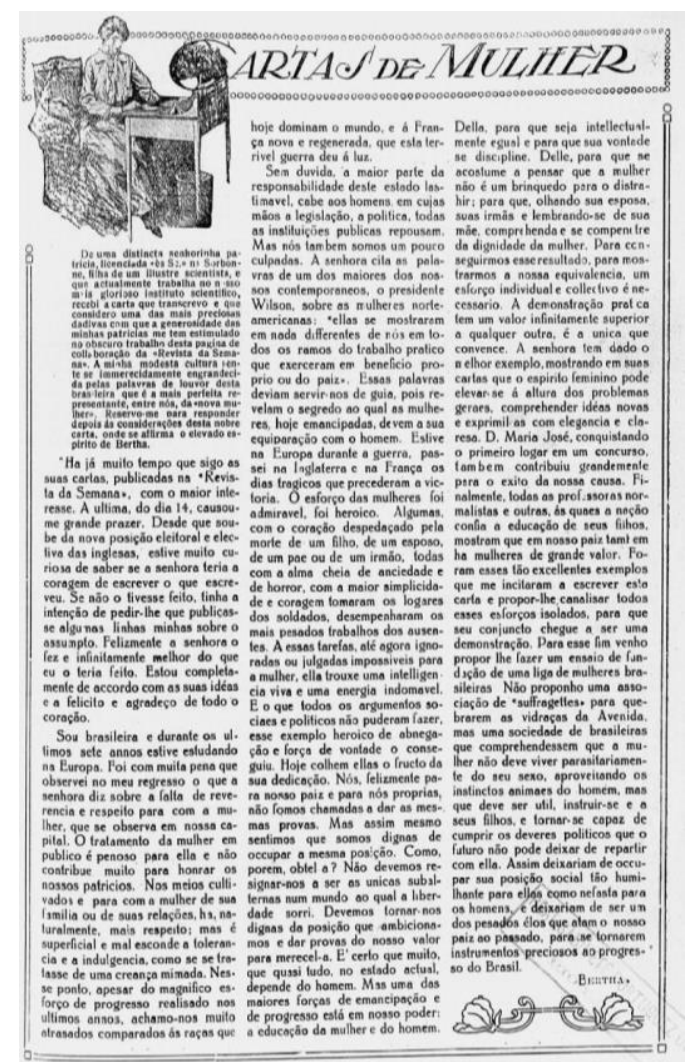

Figura 5: Bertha Lutz propõe, numa matéria da Revista da Semana, em 28 de Dezembro de 1918, página 19, uma sociedade brasileira mais compreensiva, na qual a mulher deve ser útil e não apenas uma figura decorativa. 
Bertha Lutz continuou a fazer suas participações na imprensa, conjugando suas duas facetas mais famosas: a de líder feminista brasileira, como passou a ser conhecida do público, e também a de cientista. Em fevereiro de 1922, o jornal O Paiz publicou uma nota de nomeação de Bertha Lutz, pelo Ministério da Justiça, como representante brasileira a tomar parte na Conferência Pan-Americana de Mulheres, que se reuniria em abril do mesmo ano em Baltimore, nos Estados Unidos. Como não se licenciou do cargo de secretária do Museu Nacional, Bertha Lutz continuou com dupla missão, pois além de participar da conferência deveria, segundo Sousa31, "permutar material científico, visitar e estreitar relações nos museus e também em instituições de ensino de Economia Doméstica." Ou seja, "a observação de "políticas" e "ciências" eram dimensões inseparáveis na vida de Lutz."

Lino ${ }^{32}$ evidencia a americana Carrie Chapman Catt como uma grande influência ideológica para o movimento feminista brasileiro, quando presidente da National American Woman Suffrage Association (NAWSA), a principal e mais numerosa associação feminista e sufragista americana. Fundada em 1890, a partir da fusão de outras duas associações, a NAWSA foi se tornando mais conservadora ao longo dos anos, inclusive se utilizando de métodos questionáveis como excluir as mulheres negras do movimento em função da tradição escravista e segregadora herdada nos estados do sul, além de marcar posição contrária ao voto de imigrantes para obter o apoio dos homens de classe média. Sob a tutela de Carrie Catt, que assumiu presidência da NAWSA em 1916, o grupo tornou-se ainda mais elitista, pois passou a aceitar apenas quem daria dedicação exclusiva a causa, o que excluía todas as pessoas que trabalhavam ou possuíam outras atividades. Carrie Catt esteve no Brasil em 1922 e inspirou as ideias de Bertha Lutz a partir deste momento.

Em 1922, a Liga para a Emancipação Intelectual da Mulher foi substituída pela Federação Brasileira para o Progresso Feminino (FBPF). Seus fins estavam explicitados em seus estatutos, no artigo 3:

1. Promover a educação da mulher e elevar o nível da instrução feminina;

2. Proteger as mães e a infância;

3. Obter garantias legislativas e práticas para o trabalho feminino;

4. Auxiliar as boas iniciativas da mulher e orientá-la na escolha de uma profissão;

5. Estimular o espírito de sociabilidade e cooperação entre as mulheres e interessá-las pelas questões sociais e de alcance publico;

6. Assegurar à mulher os direitos políticos que a nossa Constituição Ihe confere e prepará-la para o exercício inteligente desses direitos;

\footnotetext{
${ }^{31}$ Lia G. P. Sousa, "Educação e Profissionalização de Mulheres: Trajetória Cientifica e Feminista de Bertha Lutz no Museu Nacional do Rio de Janeiro (1919-1937)" (dissertação de mestrado em História das Ciências e da Saúde, Fundação Oswaldo Cruz, 2009 ): 70.

32 Sonia C. F. M. Lino, "As Ideias Feministas no Brasil (1918-1932)" (dissertação de mestrado em História do Brasil, Universidade Federal do Paraná, 1986).
} 
7. Estreitar os laços de amizade com os demais países americanos a fim de garantir a manutenção perpétua da paz e da justiça no Hemisfério ocidental. ${ }^{33}$

Apesar de expressar em seus estatutos a luta por melhores condições de trabalho, na prática a luta da Federação se aproximou mais do movimento sufragista americano, lutando apenas pelas vias legais e nos meandros da política, esperando sempre atender expectativas de bom comportamento associadas às mulheres, avançando em suas demandas pela persuasão aos homens de que a ordem social não estava ameaçada e evitando temas mais polêmicos como a condição de vida das operárias.

Esse afastamento da causa da mulher operária foi duramente criticado pela escritora Rachel Prado (1891-1943) em entrevista ao periódico A Esquerda, em 23 de Março de 1931 (figura 6). Rachel Prado reconheceu qualidades em Bertha Lutz, porém, considerava-a afastada demais da verdadeira realidade da mulher brasileira, como se estivesse mais próxima do feminismo internacional que de seu próprio país.

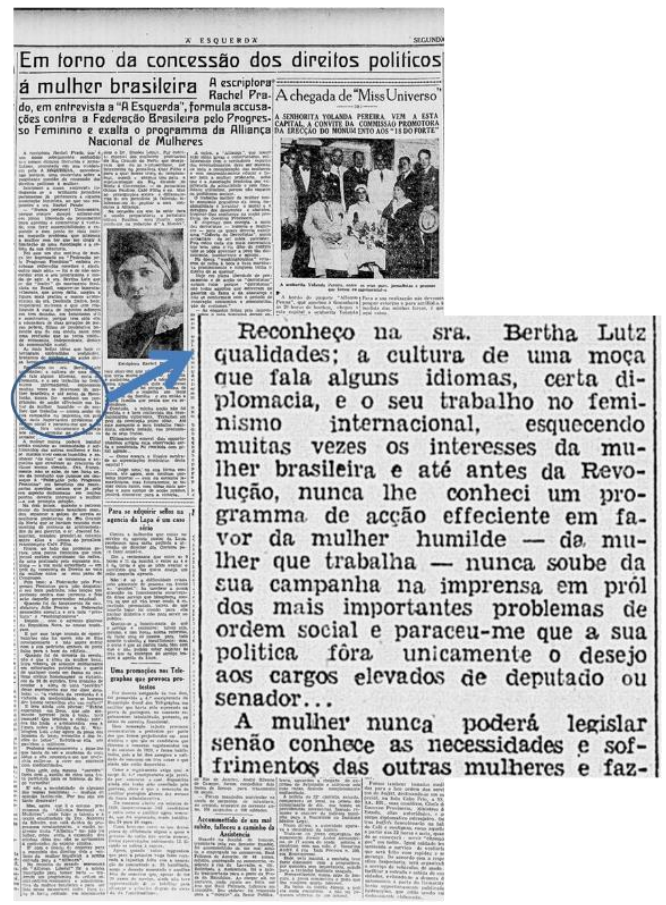

Figura 6: Rachel Prado e suas críticas a Federação pelo Progresso Feminino na Revista A Esquerda, em 23 de Março de 1931.

Ainda em 1922, Bertha Lutz participou da organização do Primeiro Congresso Internacional Feminista, que ocorreu nos salões do Automóvel Club no Rio de Janeiro. O congresso contou com a convidada norte-americana Carrie Catt como divulgado no jornal O Paiz, em 1922.

33 lbid., 58. 
Durante toda a década de 1920, a Federação e Bertha Lutz se mantiveram ativas na militância, principalmente no estreitamento de alianças nacionais e internacionais. Em 1923, participou do Congresso Feminista de Roma e viajou a Bélgica para estudar, entre outros assuntos, os tipos de escola de economia doméstica com aplicação agrícola, como noticiado no Jornal O Paiz, em 1923, na página dois. Em 1924, o Jornal do Brasil mostrou a visita do Dr. Paul de Vuyst, diretor geral do Ministério de Agricultura da Bélgica em sua visita ao Rio de Janeiro, acompanhado por Bertha Lutz.

Em 1925, Bertha Lutz participou da Conferência Interamericana de Mulheres, desta vez sediada em Washington. Na volta ao Brasil, proferiu algumas palavras no Jornal Correio da Manhã sobre várias associações femininas formadas nos Estados Unidos, como Liga de Mulheres Eleitoras, para formação do eleitorado feminino; Federação de Clubes de Senhoras, organização feminina que se reunia para sessões de arte, literatura, música e conferências para formar o espírito cívico; Federação Internacional de Ex-Alunas de Escolas Superiores e Universidades, proporcionando oportunidade de estudo para carreiras liberais e, a que mais Ihe chamou a atenção, Associação Católica de Senhoras, que mantinha uma escola de preparo social. Bertha Lutz citou ainda visitas a museus e estabelecimentos científicos onde observou trabalhos sobre Biologia, demonstrando mais uma vez sua dupla missão, política e científica, e seu apreço especial pela organização.

Em 1926, Marie Curie visitou o Brasil a convite do extinto Instituto Franco-Brasileiro de Alta Cultura, - instituição mantida pela embaixada francesa no Rio de Janeiro - destinado à educação e divulgação científica. Durante vários dias, a chegada iminente da cientista francesa foi noticiada e uma comitiva de especial prestígio foi destacada para ciceroneá-la. Dentre os membros da comitiva estava Bertha Lutz (figura 7), tendo a FBPF integrada nas homenagens prestadas a Marie Curie. A imprensa fez cobertura do evento e inclusive publicou uma grande matéria, de primeira página, com descrição do trabalho da cientista francesa e uma foto com a filha mais velha, Irene Curie (figura 8). 


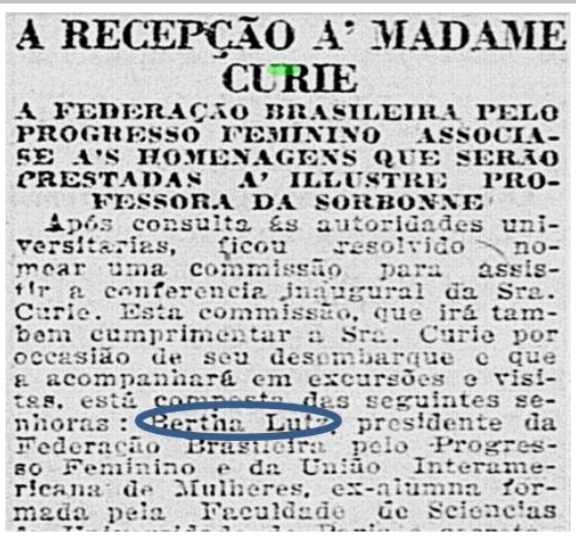

Figura 7: Bertha Lutz recebe papel de destaque na recepção a cientista Madame Curie no Brasil como noticiado no jornal Gazeta de Notícias, em 13 de Julho de 1926, página 2.

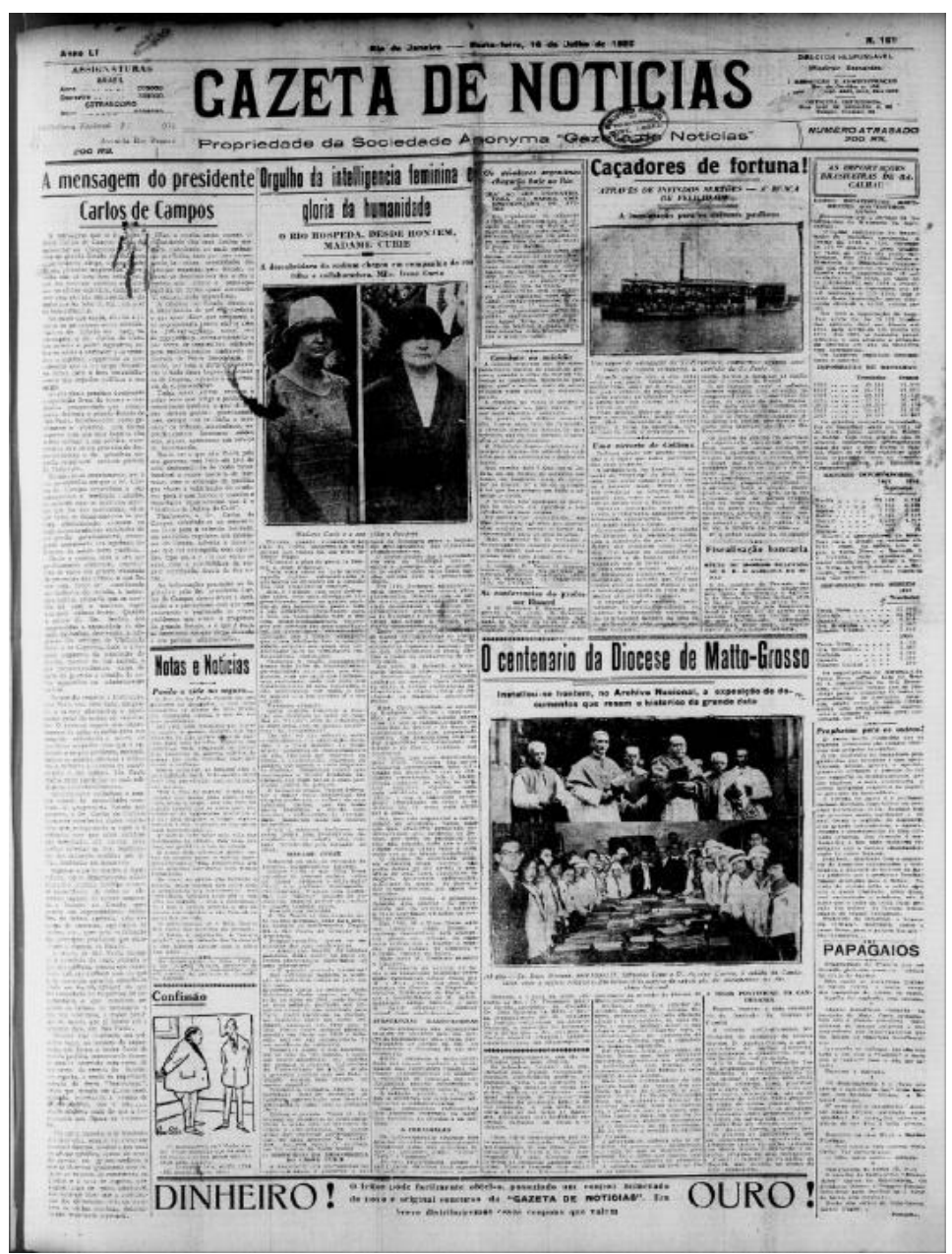

Figura 8: Matéria do jornal Gazeta de Notícias, em 16 de Julho de 1926, sobre a visita de Madame Curie e sua filha mais velha ao Rio de Janeiro.

Bertha Lutz também participou da fundação da União Universitária Feminina (UUF), posteriormente denominada Associação Brasileira de Mulheres Universitárias, em 1929. A figura 9 
mostra como as ações e o movimento feminista eram noticiados por parte da imprensa na década de 1920.

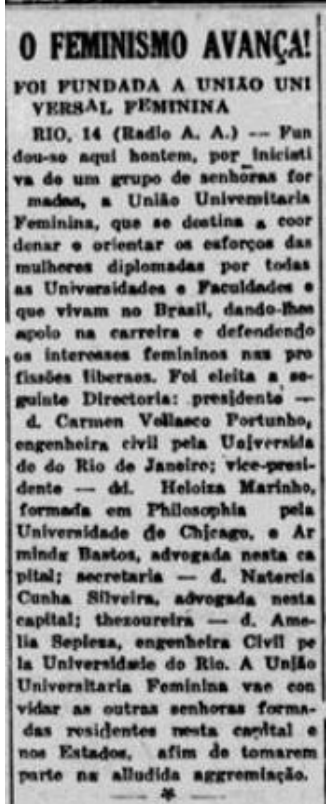

Figura 9: Fundação da União Universitária Feminina presente no jornal O Paiz, em 15 de Janeiro de 1929.

\section{A ENTRADA FORMAL NA POLÍTICA E O PERÍODO COMO DEPUTADA FEDERAL}

Nos anos de 1927 e 1928, a campanha pelo sufrágio feminino no Brasil voltou a carga. 0 projeto número 102, de 1919, - também conhecido como projeto Chermont por ter sido apresentado pelo senador Justo Chermont, do Pará -, havia sido abandonado apesar do parecer favorável que teve à época, somente voltando a ser discutido em 1927. As feministas da Federação usaram, então, de seus contatos no mundo político para se aproximar de senadores favoráveis ao projeto e firmar uma campanha forte junto à imprensa. Um dos partidários do voto feminino era Juvenal Lamartine de Faria, senador pelo estado do Rio Grande do Norte, que retornou a seu estado para concorrer ao governo. No ano seguinte, 1928, várias mulheres potiguares foram habilitadas a votar, porém tais votos não foram reconhecidos como válidos pelo senado.

Bertha Lutz iniciou, então, uma nova graduação, em direito, pela Faculdade de Direito do Rio de Janeiro e passou a participar também de organizações que discutiam e propunham novos adendos a Constituição, além de se lançar candidata a constituinte. A consolidação de sua plataforma eleitoral foi a publicação do livro "Os 13 princípios básicos: sugestões ao anteprojeto da Constituição":

Eis, segundo a autora, os princípios que deveriam nortear a Constituição a ser redigida: racionalização do poder, organização da economia, dignificação do 
trabalho, nacionalização da saúde, generalização da previdência, socialização da instrução, democratização da justiça, equiparação dos sexos, consagração da liberdade, proscrição da violência, soerguimento da moral, flexibilidade do direito e dinamização da lei. ${ }^{34}$

Em 1932, o voto feminino foi assegurado no Brasil. Naquele mesmo período, o discurso de Bertha Lutz assumiu um tom ainda mais conciliador, moderado e bem comportado para os padrões feministas. Em publicação de dezembro de 1932, na Revista Brasil Feminino, há uma coluna chamada "Feminismo" que apresenta um título interessante "O que a mulher deve querer". Por ocasião da conquista do voto feminino, a coluna expressa muita preocupação em que a mulher brasileira se mostre digna dos direitos que conquistou e não crie "dificuldades" a partir de suas "paixões exaltadas, os partidarismos extravagantes, a desordem de vontades, não venham a criar às duas delegadas da mulher brasileira, junto aos que vão legislar para a reintegração da nossa pátria nos princípios básicos que orientam as nações, dificuldades dispersadoras de energias e pensamentos".

O jornal O Radical faz duras críticas a Bertha Lutz, considerando um ultraje que uma tão notória feminista, tendo oportunidade de se apresentar à comissão do anteprojeto da Constituição, trate sobre o reflorestamento antes de tratar das pautas mais femininas urgentes como a maternidade, 0 trabalho nas fábricas, a primeira infância, a igualdade de salários, entre outros (figura 10).
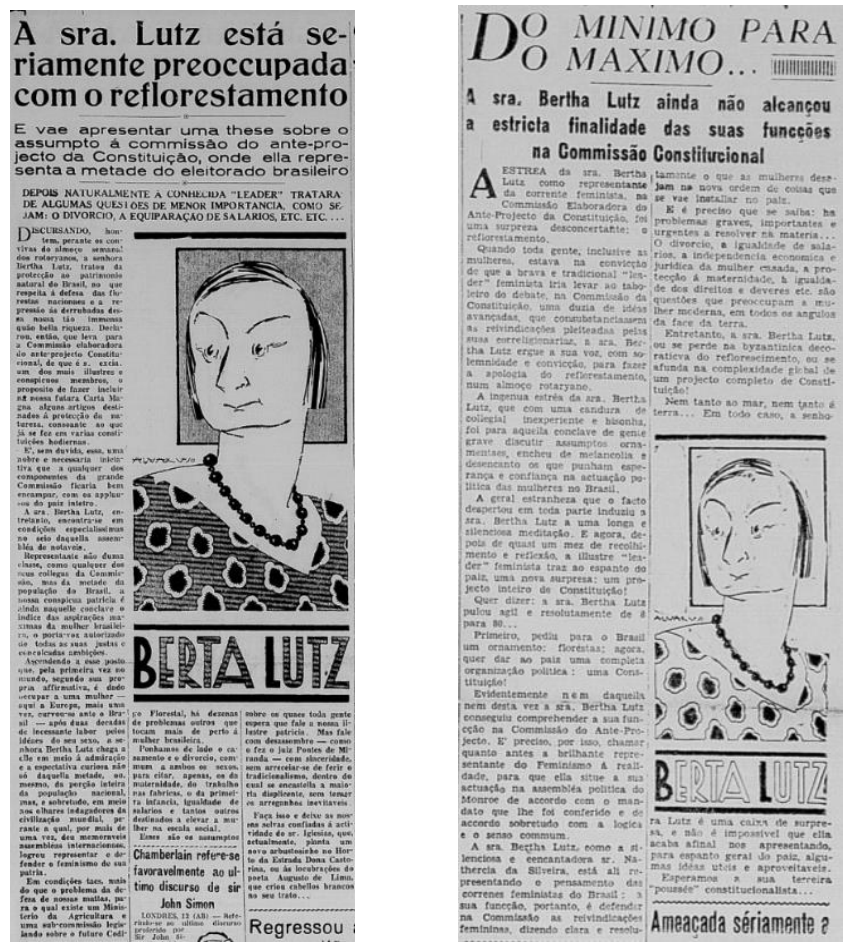

Figura 10: Duras críticas ao tema escolhido por Bertha Lutz no jornal O Radical, em 14 de Dezembro de 1932.

34 Marques, 55. 
No entanto, este mesmo jornal não se furtou a dar o devido destaque a Bertha Lutz quando do tratamento de causas genuinamente femininas. Tendo tomado posse do cargo de deputada federal em 1936, a líder feminista passou a atuar diretamente na câmara contra o desamparo da Educação, da maternidade e da infância como mostra a matéria do jornal O Radical (figura 11), bem como mostrouse incansável na defesa dos direitos da mulher funcionária, no mercado de trabalho e na defesa das instituições científicas (figura 12).

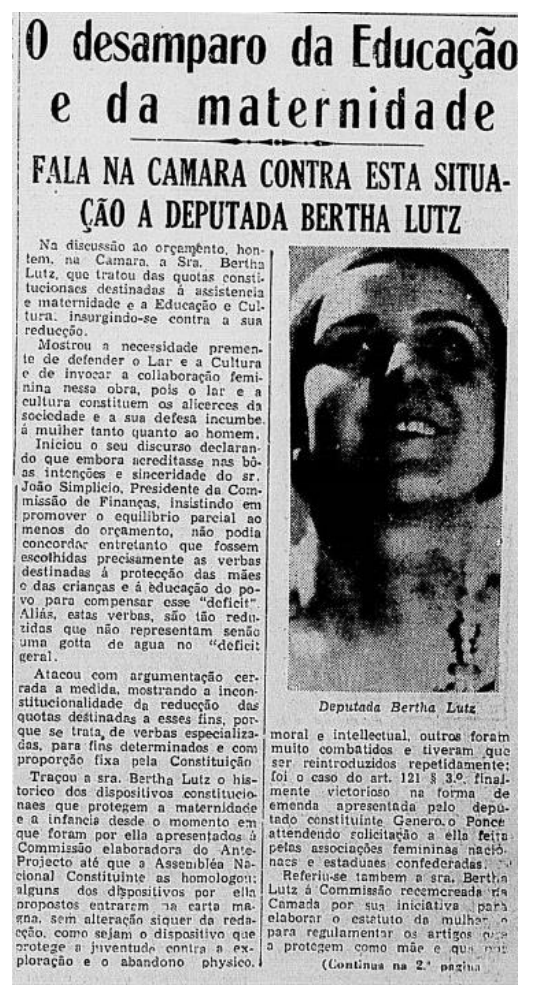

Figura 11: Bertha Lutz no jornal O Radical, em 1936. 


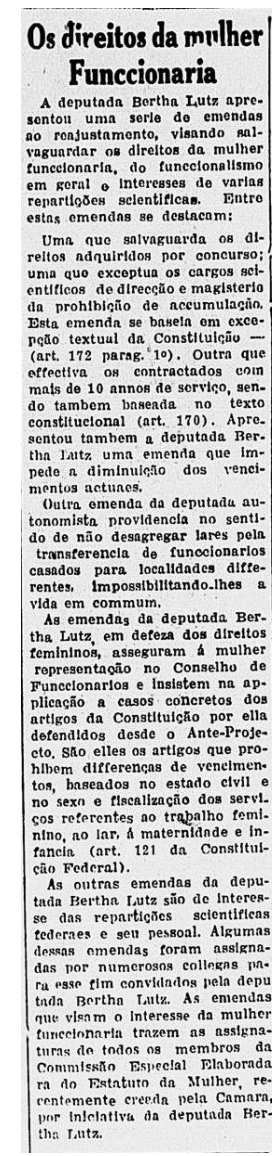

Figura12: A deputada Bertha Lutz em sua luta pelos direitos da mulher no mercado de trabalho no jornal A Batalha, em 1936.

Durante seu mandato, Bertha Lutz fez uma proposição que garantiria ampla reformulação dos direitos jurídicos da mulher, o Estatuto da Mulher. Nele há inúmeras propostas; o projeto final continha cerca de 150 artigos, tratando de muitos aspectos da vida das mulheres no país, como o poder conjugal, o pátrio poder, direitos de propriedade, direito penal e assistência à saúde e acesso às carreiras científicas.

O projeto avançou na comissão especial que Bertha Lutz conseguira criar e presidir, desde fins de 1936. Os integrantes da comissão já o haviam discutido duas vezes quando o Congresso foi fechado em 10 de novembro de 1937. Em tal estatuto, segundo Soihet, a Educação, formação superior e científica mereceu uma especial atenção de Bertha Lutz, com artigos específicos que garantiam a entrada de mulheres no ensino secundário oficial e garantiam também direitos à instrução idênticos aos dos homens.

Sousa enfatiza a apropriação de Bertha Lutz à agenda política, educacional e científica de seu tempo, ao considerar uma via para a emancipação da mulher em termos restritos aos ambientes domésticos. Por isso, sua ação voltou-se para a Educação superior e científica feminina pela via da economia doméstica. Além disso, com sua ligação ao Ministério da Agricultura e a predominância da 
atividade agrícola no Brasil no início do século XX, muitas vezes seus esforços se concentraram na área do ensino agrícola, do ensino doméstico e do ensino superior, como uma forma de inserir a mulher no mundo da pesquisa e da carreira científica. Em quase todas as viagens internacionais que participou, sem se licenciar de seu cargo no MN, houve um intenso contato com inúmeras escolas agrícolas e domésticas pelo mundo, principalmente, nos Estados Unidos, Inglaterra, Bélgica e Alemanha.

Em 1922, representando a Federação Brasileira pelo Progresso Feminino, e também o MN, Bertha Lutz participou do Congresso Brasileiro de Ensino Secundário e Superior, e defendeu a entrada de mulheres no Colégio Pedro II. Naquela época, o colégio era a principal instituição de ensino secundário do Rio de Janeiro e porta de entrada para o ensino superior. Mais tarde, em 1931, Bertha esteve presente na formatura da primeira aluna a receber 0 grau de bacharel em tal instituição. ${ }^{35}$

Outro campo importante no qual Bertha Lutz foi uma pioneira no Brasil foi a área Educação em Museus, um tema pouco abordado na época, ainda voltado para o modelo colecionista-classificatório dos museus de ciências do país. Em suas viagens internacionais realizou muitas visitas a museus de ciências (mais de cinquenta instituições científicas no período de 1925 a 1932) com o intuito de estudar a dimensão pedagógica dos museus, e promover mudanças na relação público-exposição. Suas observações foram compiladas em um extenso relatório, publicado como livro quase oito décadas depois, intitulado "A Função Educativa dos Museus". ${ }^{36}$

[...] na realidade, até as últimas décadas, os museus tinham descurado um tanto 0 aspecto popular de sua função educativa. [...]. As coleções eram organizadas de modo a facilitar as investigações científicas, não obstante a aridez desta modalidade de exposição. Por grande favor admitia-se o público a percorrer as salas e ler os rótulos anexados aos espécimes [...], e nos museus de arte, ao nome do autor da obra, sua data de nascimento e de morte. Agora não é mais assim. O museu contemporâneo está começando a adquirir consciência de seu papel de esclarecedor da massa do povo e a envidar todos os esforços nesse sentido. ${ }^{37}$

\footnotetext{
${ }^{35}$ Rosana L. Alves, "Trajetórias Femininas no Colégio Pedro II," in ANPUH - XXV Simpósio Nacional de História, 1-10 (Fortaleza, 2009), 5.

${ }^{36}$ Este livro foi publicado pelo Museu Nacional e pela editora Muiraquitã, — com apoio da FAPERJ e organização de Guilherme Gantois de Miranda, Maria José Veloso da Costa Santos, Silvia Ninita de Moura Estevão e Vitor Manoel Marques da Fonseca, em 2008 -, a partir dos arquivos existentes no MN e no Arquivo Nacional referentes à Bertha Lutz.

${ }^{37}$ Bertha Lutz, A Função Educativa dos Museus, org. Guilherme G. de Miranda et al. (Rio de Janeiro: Museu Nacional, UFRJ; Niteroi: Muiraquitã, 2008), 31.
} 
Neste amplo relatório de caráter inovador para época ${ }^{38}$ e ainda atual e significativo para a temática, salientou diversos aspectos como localização, arquitetura, horário de funcionamento, rotinas de trabalho, tipos de exposição, relação museu-escola; indicou referências bibliográficas, fontes de estudo; incorporou fotografias, fichas de catalogação, folhetos e, inclusive, destacou a quantidade de mulheres funcionárias "um dos aspectos da atividade dos museus americanos que mais me interessou foi verificar como é grande o número de mulheres que nele exercem a sua atividade". ${ }^{39}$

Bertha também sugeriu a utilização do Museu Nacional na esfera dos cursos superiores e de especialização, que eram dispersos no país. Defendeu também a formação para mulheres como educadoras nos museus, e como parte desta formação, cursos de Ciências Naturais seriam oferecidos pelos próprios museus, conferindo uma oportunidade de especialização científica às mulheres e ao magistério. 40

Lôbo descreve uma atuação muito interessante de Bertha Lutz no congresso, em 1937, sobre a formação científica de uma forma geral, ao apresentar uma emenda ao dispositivo que criava uma única Faculdade de Filosofia, Ciências e Letras. Ela defendia a separação das ciências da Filosofia, por entender que as ciências referidas englobavam Ciências Físicas, Matemáticas e Naturais, que diferenciavam essencialmente das reflexões filosóficas e do ensino de Letras. Em suas palavras "da ciência e das suas aplicações técnicas decorre o progresso contínuo e sistemático da humanidade."41

Sua preocupação com a ciência em si era tanta que, a partir deste ponto, Bertha lutou para mudar seus rumos no Brasil, com ações voltadas em prol do desenvolvimento da cultura científica dentro e fora da universidade. Além de se posicionar na inclusão da pesquisa científica na universidade, - aspecto que foi muito debatido e pressionado pela $A B C, S B P C$, tempos mais tarde ${ }^{42}$ —, defendeu, sobretudo, que a universidade se desenvolvesse no Brasil de acordo com um modelo que abarcasse as funções de pesquisa e extensão ao lado do ensino.

Nessa luta pela educação científica em geral, essa cientista e ativista das causas feministas também aspirou participar e promover a formação científica das mulheres, propondo ao congresso, em 1936, a criação da Faculdade de Ciências Domésticas e Sociais, que seria responsável pela formação de assistentes sociais e enfermeiras. Sua convicção era que "é preciso estudar cientificamente o ambiente e preparar técnicas para torná-las eficientes. Há muitos empreendimentos de caridade que

\footnotetext{
${ }^{38}$ Lopes, "Bertha Lutz e a Importância das Relações de Gênero, da Educação e do Público nas Instituições Museais," Musas - Revista brasileira de museus e museologia, $n^{\circ}$ 2, (maio 2006): 41-47; e Lopes, A Construção da Invisibilidade das Mulheres nas Ciências: A Exemplaridade de Bertha Maria Julia Lutz (1894-1976)," Revista Gênero 5, nº 1 (2004): 97-109.

39 Lutz, 77.

40 Sousa, "Educação e Profissionalização de Mulheres".

41 Lôbo, Bertha Lutz, 16.

${ }^{42}$ Marta F. Abdala-Mendes, "Uma Perspectiva Histórica da Divulgação Científica: A Atuação do Cientista-Divulgador José Reis (19481958)" (tese de doutorado, FIOCRUZ, Rio de Janeiro, 2006).
} 
não produzem o resultado que poderiam produzir por falta de preparo técnico dos elementos que os dirigem." 43

Estas batalhas no parlamento renderam duas derrotas para Bertha Lutz. O ensino de Ciências ficou mesmo subordinado à Faculdade Nacional de Filosofia, Ciências e Letras. E o ensino de Enfermagem e o de Serviço Social, que na época eram tão caros à formação das mulheres, ficaram relegados a uma instituição complementar, a Escola Ana Néri, incapaz, portanto, de oferecer diploma de nível superior às concluintes.

Num período em que "em que os cientistas priorizaram e dedicaram-se eles próprios às suas pesquisas, à educação e à divulgação científica"44, Bertha atuou e realizou suas pesquisas e atividades científicas no Museu Nacional referenciadas pelos problemas nacionais mas apoiadas em estudos internacionais. Em concordância com o que Lopes destaca sobre a importância do pensamento de Bertha Lutz, ampliamos com este artigo o "convite à necessária reflexão sobre as possibilidades analíticas que (...) oferecem aos historiadores em geral, aos historiadores das ciências, aos estudiosos de gênero, para nos ajudar a pensar o século XXI."45

\section{CONSIDERAÇÕES FINAIS}

Neste estudo, procuramos abordar as contribuições desta cientista e feminista, para o campo da formação científica e profissional das mulheres. Toda a trajetória política e científica de Bertha Lutz foi construída em torno dos ideais feministas do início do século $\mathrm{XX}$, baseada na ideia de que as mulheres possuem um enorme potencial que é desperdiçado quando se relega seu papel na sociedade ao segundo plano, a uma vida reclusa e subordinada aos homens.

Ainda hoje, o caminho a ser trilhado pelas mulheres na ciência encontra mais percalços que 0 de homens, uma vez que recebem menor remuneração por atuação na mesma função e ainda são inferiorizadas única e exclusivamente por causa do gênero. A palavra gênero também vem ganhando ares cada vez mais polêmicos nos últimos anos e foi, inclusive, retirada da última versão do Plano Nacional de Educação. A recusa em sequer discutir o assunto, principalmente nas escolas, não fará a diferença entre os gêneros desaparecer e pode contribuir para a manutenção desta desigualdade. ${ }^{46}$

Nas ciências, como em outras áreas do conhecimento, há um silenciamento histórico das mulheres ${ }^{47}$. A visibilidade da atuação de mulheres como produtoras de conhecimento nas ciências pode trazer vivências distintas e acrescentar novas visões capazes de mudar a forma de fazer e

\footnotetext{
${ }^{43}$ Marques, 122.

44Lopes, "Convite à Leitura," in A Função Educativa dos Museus, Bertha Lutz, org. Guilherme G. Miranda et al. (Rio de Janeiro: Museu Nacional; Niterói: Muiraquitã, 2008): 20.

$45 \mathrm{lbid}, 23$.

${ }^{46}$ Haraway, "Saberes Localizados"; Furlani, Ideologia de Gênero?

${ }^{47}$ Segundo a matéria no jornal on line EL PAÍS, de 14 de outubro de 2016, homens ganharam 97\% dos Nobel de ciência desde 1901.
} 
compreender a ciência, ou podem, como aconteceu no Brasil no início do século passado, se associar ao discurso já estabelecido, demonstrando seu valor para garantir seu espaço, que se constitui como uma forma de luta pela resistência.

Uma das cientistas mais famosas no mundo, Marie Curie, causou alvoroço há mais de 100 anos, porém o ambiente para mulheres cientistas ainda se apresenta bastante hostil, apesar de ter melhorado nas últimas décadas. No Brasil, há uma iniciativa do CNPq, em parceria com a Secretaria de Política para as Mulheres, no âmbito do Programa Mulher e Ciência, chamada "Pioneiras da Ciência no Brasil", que busca resgatar histórias femininas na história da ciência em nosso país e inspirar as novas gerações.

Ainda que tenhamos trazido representações e práticas sobre a mulher na ciência, a partir do estudo de uma cientista e feminista tão importante para a história da ciência no Brasil, percebemos os avanços no ingresso e participação da mulher na vida pública e na carreira científica. Nosso intuito com esse estudo foi evidenciar a importância a ser dada as contribuições das cientistas tanto do passado como dos tempos atuais, mesmo que continuamos a enfrentar, ainda, muitos desafios na busca pela igualdade de gêneros.

\section{SOBRE AS AUTORAS:}

Maria Izabel Siciliano de Souza

(e-mail: missbelsiciliano@gmail.com)

Marta Ferreira Abdala-Mendes

Instituto Federal do Rio de Janeiro (campus Mesquita)

(e-mail: marta.mendes@ifrj.edu.br)

Artigo recebido em 29 de abril de 2018

Aceito para publicação em 30 de junho de 2018 